\title{
Kestävyyttä kohden?
}

\section{Kalastuksen säätelyn tietoperustaisuus ja hyväksyttävyys Lieksanjoen Ruunaan koskilla}

DOI: https://doi.org/10.51807/maaseutututkimus.109150

Virkistyskalastus lukeutuu Suomen suosituimpiin harrastuksiin. Kalastusta ohjataan ensisijaisesti erilaisilla pyyntiväline- ja aikarajoituksilla sekä saaliskiintiöillä, joiden avulla pyritään turvaamaan kalakantojen säilyminen ja pyynnin kestävyys. Kestävässä virkistyskalastuksen säätelyssä kyse ei ole pelkästään kalastuksen aiheuttaman suoran kuolleisuuden rajoittamisesta, vaan toiminnassa on huomioitava myös muut kalastuksen aiheuttamat vaikutukset. Artikkelissa tarkastellaan kalastuksen säätelyn tietoperustaa ja hyväksyttävyyttä Lieksanjoen Ruunaan koskilla. Tutkimusaineistona käytetään Ruunaan kalastajille kohdennetun kyselyn vastauksia. Tulokset osoittavat, että kalastuksen säätely on Ruunaalla edennyt kohti aiempaa tietoperustaisempaa ja kestävämpää suuntaa, mutta säätelyssä on kuitenkin jäljellä kestävyysvajetta. Aineistojen mukaan säätelyä on mahdollista kehittää nykyisestä ja näin edistää kalastusharrastuksen kokonaisvaltaista kestävyyttä. Tulosten perusteella virkistyskalastajat ovat monimuotoinen harrastajien joukko, mikä on huomioitava alueellisia kalastusjärjestelyitä ja -säätelyä kehitettäessä.

Asiasanat: Virkistyskalastus, säätely, ekologinen kestävyys, sosiaalinen kestävyys, Ruunaan kosket 
$\mathrm{K}$ alastus on suosittu harrastus. Noin 1,5 miljoonaa suomalaista kalastaa vuosittain (LUKE, Vapaa-ajankalastuksen tilastot 2018), mutta kyse on myös kansainvälisesti suositusta lajista. Maailmanlaajuinen kalastusharrastajien määrä on satoja miljoonia, ja virkistyskalastajat ovat merkittävimpiä kalavarantojen hyödyntäjiä teollistuneissa maissa. (Arlinghaus ym. 2013, 91.) Kalastajien määrä ja kalavarantojen rajallisuus vaikeuttavat pyynnin sovittamista kestävälle tasolle. (Cooke ym. 2019, 846.) Kalastajia ohjataan pääsääntöisesti pyyntikiintiöiden sekä aika- ja pyyntivälinerajoitusten avulla, joilla turvataan kalakantojen säilymistä ja pyritään takaamaan pyynnin kestävyys. (Muje ym. 2019, 49.) Säätelyssä on kuitenkin usein haasteita koskien niin säätelymenetelmien tietoperustaisuutta kuin kalastajien sekä säätelyn välisen suhteen ymmärrystä. Yksinkertaisimmillaan haasteet tulevat esiin siten, että säätelystä puuttuu täysin jokin tarpeellinen ja hyvin tunnettu mekanismi: esimerkiksi pyyntikiintiö. Vastaavasti kalastajien ja säätelytoimien välinen suhde ei ole täysin yksiselitteinen. Kalastajat voivat osaltaan toivoa tiukempaa säätelyä, mutta he voivat myös suhtautua kriittisesti oikein kohdennettuihin säätelytoimiin, mikäli heillä ei ole riittävää tietoa säätelyn tavoitteista ja tosiasiallisesta vaikuttavuudesta.

Lähestyn tässä artikkelissa virkistyskalastusta ja sen säätelyä kotimaisen tapaustutkimuksen kautta. Tutkimus keskittyy valtakunnallisesti tunnettuun virkistyskalastuskohteeseen, Lieksanjoen Ruunaan koskireittiin. Ruunaan kosket ovat Metsähallituksen suosituin kalastusalue, jonne myydään vuosittain tuhansia kalastuslupia. (Eräluvat.fi, 29.12.2020.) Käytän aineistona Ruunaan kalastajille kohdennettuun elektroniseen kyselyyn saapuneita vastauksia. Tutkimus nivoutuu osaksi kalastajien kokemustiedon tutkimusperinnettä (Fishers' knowledge research) (esim. Hind 2015).

Tutkimuksessa tarkastelen kalastajien, kohteen kalastussääntöjen ja kestävän säätelyn välistä suhdetta. Tutkimuskysymykseni ovat: 1. millainen suhtautuminen kalastajilla on Ruunaan koskien kalastuksen säätelyyn, sekä 2. kuinka tietoperustaista kohteen kalastuksen säätely on. Vastaan kysymyksiin tutkimalla kohteen kalastussääntöjä, hyödyntämällä kansainvälistä kalastustutkimusta, sekä analysoimalla kalastajakyselyn vastauksia.

Kalastuksen kestävyydessä kyse on lähtökohtaisesti ekologisesta kestävyydestä, mutta siihen kytkeytyy kiistatta myös sosiaalinen taso. Ekologinen kestävyys on kalastuksen jatkuvuuden ytimessä: kalastus on 
mitoitettava kalakannan sietokyvyn mukaan. (Pauly ym. 2002.) Sosiaalisen kestävyyden kohdalla huomioidaan kalaresurssia hyödyntävien ihmisten tarpeet ja käsitykset esimerkiksi osallisuudesta ja pyynnin järjestämisestä sekä säätelyn toimivuudesta. (Steelman \& Wallace 2001.)

Tietoperustainen kalakantojen hallinta hyödyttää lopulta niin kalastajia kuin kaloja, mutta myös maaseutualueiden elinkeinoja. Kestävästi hyödynnetty kalaresurssi mahdollistaa liiketoimintaa esimerkiksi taloudellisesti merkittävän erämatkailun muodossa. (Pohja-Mykrä ym. 2018, 9.) Kotimaan maaseutualueiden kalastuskohteiden määrä huomioiden kysymys kalastuksen kestävyydestä ja säätelystä sekä kalakantojen tietoperustaisesta hallinnasta kokonaisuudessaan on perin merkityksellinen. Tutkimukseni tavoite on paitsi lisätä tietoisuutta kestävistä käytännöistä ja kalastajaryhmien tuntemuksesta, myös nostaa esiin kriittisiä kysymyksiä kalastuksen säätelyyn liittyen.

Tutkimuksen keskeisimmät taustateoriat ovat kestävyys ja tietoperustaisuus. Suhde tietoon ja erilaiset käsitykset tiedosta ovat merkityksellisiä kalastuksen säätelylle ja noudattamiselle (esim. Hunt ym. 2013), sillä ne sitovat ekologisen ja sosiaalisen kestävyyden tasoja yhteen. Kyse on tiedosta, jonka varaan säätely rakentuu, sekä siitä, kuinka säätelyn kohteena olevat toimijat ymmärtävät säätelytoimien vaikuttavuuden. Sosiaalisesti hyvin toimiva säätely perustuukin niin ekologisen kestävyyden takaamiseen kuin kalastajien sitoutumiseen säätelyn noudattamiseen.

Taustateoriat konkretisoituivat tutkimuksessani sekä kyselylomakkeen suunnittelussa että vastausaineiston analysoinnissa. Työssäni hyödynnän kalastuksen säätelytutkimusta sekä luonnontieteellistä tutkimusta kalojen pyytämiseen ja käsittelyyn liittyen. Näiden avulla määritän säätelyn tietoperustaisen raamin, johon vertaan Ruunaan kalastussääntöä. Tämän jälkeen tarkastelen kalastajien käsityksiä ja mielipiteitä voimassa olevasta säätelystä.

\section{Kestävän kalastuksen säätelyn kaksi tasoa}

Kalastuksen kestävyydestä voidaan erottaa neljä ulottuvuutta: ekologinen, sosio-ekonominen, yhteisöllinen ja institutionaalis-sosiaalinen. (Charles 2001, 188-190.) Ekologisen kestävyyden takaamiseen liittyy perinteisesti kalapopulaatioiden koon ja elinvoimaisuuden selvittäminen. Sen avulla kalastukselle voidaan määrittää laskennallisesti kestävät 
pyynnin maksimikiintiöt (MSY, Maximum sustainable yield), jotta pyynti ei heikentäisi liikaa kalakantaa ja siten vaarantaisi sen säilymistä. (Cooke ym. 2018, 847.) Kokonaisvaltaiselle kestävyydelle merkityksellisiä ovat myös kalastuksessa käytettävät menetelmät ja niiden kaloille aiheuttamat vaikutukset. Kalastuksen säätelyyn liittyy osaltaan myös sosiaalinen kestävyys, joka kohdataan tarkasteltaessa kalastajien suhtautumisesta eri säätelytoimiin. Seuraavaksi esittelen työni keskeiset ekologisen ja sosiaalisen kestävyyden piirteet.

\section{Oikeat menetelmät ekologisen kestävyyden takeena}

Virkistyskalastuksen säätelyssä kyse on yksinkertaisimmillaan institutionaalista normiohjauksesta, jolla määritellään pyydettävät kalalajit ja kiintiöt sekä luvalliset pyyntivälineet ja -ajat. (Muje ym. 2019, 49.) Säätelyn on vastattava alueellisia ominaispiirteitä kalakantojen, ympäristön ja kalastuskulttuurin osalta. Nykyisin kyse ei välttämättä ole enää pelkästä yksittäisen kalalajin suojelusta, vaan säätelyn syvimpänä tavoitteena tulisi olla laajempi ekologinen kestävyys, joka huomioi koko akvaattisen ympäristön ja siellä elävien lajien väliset yhteydet. (Cooke ym. 2019, 847.)

Kalastuksen aiheuttamista vaikutuksista keskeisin on kalastuskuolleisuus, joka voi olla tarkoituksellista tai välillistä. Tarkoituksellisuus toteutuu tilanteessa, jossa kalastaja ottaa kalan saaliikseen, ja välillinen silloin, kun kalastajan vapauttama kala kuolee myöhemmin vammoihinsa. (Arlinghaus 2005, 146.) Kuolleisuuteen vaikuttavat pyyntiolosuhteet, välineet, väsytysaika ja kalojen käsittely. (Bartholomew \& Bohnsack 2005, 140-141.) Lisäksi koukutus vaikuttaa saaliskalojen kuolleisuuteen: syvälle nielty koukku aiheuttaa todennäköisesti vaikean vaurion. Syväkoukutus liittyy usein luonnonsyöttien käyttöön, jossa kalan annetaan niellä syöttiä ennen vastaiskua. (Brownscombe ym. 2017, 694.) Ruunaan koskialueella luonnonsyöttien käyttö on kielletty, jolloin tutkimus perustuu oletukseen siitä, että kalastajat tekevät vastaiskun heti kalan otin jälkeen.

Perusteet kalojen oikeaoppiselle käsittelylle ja etenkin vapauttamiselle ovat yksinkertaiset: osalla saaliskaloista on lakisääteinen alamitta, joka yksiselitteisesti määrää saaliiksi otettavien kalojen vähimmäispituuden. Lisäksi kaloilla voi olla myös pyyntikiintiö, jota ei saa ylittää. (Kalastusasetus 1360/2015, 2§.) Koska sen enempää viehe- kuin perhokalastajat 
eivät voi ennalta määrätä, millainen kala tarjottuun täkyyn ottaa, saaliskalojen vapauttamiseen päädytään ennemmin tai myöhemmin.

Tämän lisäksi saaliin valikoiminen on keskeinen toimintamalli myös kestävässä virkistyskalastuksessa, jossa pyritään varmistamaan pyydettävän kalakannan hyvinvointi. Tällöin voidaan vapauttaa esimerkiksi kooltaan huomattavan suuri yksilö, koska niiden tiedetään olevan lajin lisääntymiselle elintärkeitä. (Esim. Olin ym. 2017; Tiainen ym. 2017.) Kalan kannalta on lopulta merkityksetöntä, että tehdäänkö vapautus kalan liian lyhyen pituuden, liian suuren koon tai kenties kalastajan oman kestävyystai moraalikäsityksen mukaan. Keskeistä on turvata kaikkinainen kalojen asiallinen käsittely jo sillä yksinkertaisella eettisellä perusteella, että se on oikein, ja koska kalastajat pystyvät siihen.

Pyyntiolosuhteiden keskeisin kuolleisuuteen vaikuttava muuttuja on lämpötila. (Schisler \& Bergersen 1996, 576.) Lämpimän veden happipitoisuus on alhaisempi, mikä johtaa voimakkaampaan kalojen kokemaan rasitukseen myös ilman pyynnin aiheuttamaa stressiä. Lohikalojen kyky sietää lämmintä vettä vaihtelee, mutta kalat selviytyvät parhaiten pääsääntöisesti kylmissä vesissä. Tutkimuskirjallisuuteen perustuvana yleisenä ohjeena pidetään pyynnin rajoittamista yli +20 c vedessä, jolloin vapautettavien kalojen kuolleisuus nousee merkittävästi. (Esim. Takkunen ym. 2018.) Vastaavasti alle +20 c vedessä tapahtuvan pyynnin aiheuttaman rasituksen kuolleisuus jää useimmilla lohikaloilla hyvin alhaiseksi, 2-5\% tasoon, tai kuolleisuutta ei havaita pyyntikokeissa lainkaan. (Esim. Boyd ym. 2010, 903-904.)

Kalastusvälineissä keskeistä on vieheiden ja perhojen koukut, sekä rantauttamisessa käytettävät apuvälineet. Koukuissa merkityksellistä on niiden koon lisäksi väkäsellisyys ja lukumäärä: optimitilanteessa käytetään väkäsettömiä koukkuja, joiden määrä on mahdollisimman vähäinen ja jotka ovat vaivattomia irrottaa saaliskalasta. Lisäksi koukun muoto voi vaikuttaa myös kalan kokemiin vaurioihin. Circle-malliset koukut aiheuttavat mahdollisesti vähemmän vaurioita kuin perinteiset $\mathrm{J}: \mathrm{n}$ muotoiset koukut. (Brownscombe ym. 2017, 694.) Koukun muodosta riippumatta voidaan kuitenkin tehdä yksinkertaistus: yksihaarainen väkäsetön koukku on kiistatta helpompi irrottaa kalan suusta kuin väkäsellinen kolmihaarakoukku. Nopea ja vähän vaurioita aiheuttava koukun irrottaminen johtaa rasitusajan lyhenemiseen ja nopeampaan toipumiseen. (Bartholomew \& Bohnsack 2005, 135.) 
Haavin avulla voidaan olennaisesti lyhentää kalojen väsytysaikaa ja huolehtia ettei kalaa suojaava lima- ja suomupinta vaurioidu. Nykyiset haavit, joissa on kuminen ja solmuton havas, vaurioittavat kaloja vähemmän kuin vanhemmat havastyypit. Kun kala on haavittu, keskiöön nousevat kalan käsittely märin käsin sekä vedessä pitäminen. Kuivin käsin koskeminen voi vaurioittaa kalan limapintaa, mistä syystä vapautettavia kaloja tulee käsitellä kostutetuin käsin. (Brownscombe ym. 2017, 696-697.) Optimitilanteessa kala väsytetään mahdollisimman nopeasti, jolloin sen lihaksisto ei rasitu liikaa. Väsytyksen jatkuessa kalan elimistö kehittää lihaksistoon happoja, jotka hidastavat elpymistä. Nopea väsytys auttaa kalaa toipumaan pyyntistressistä. (Meka \& McCormick 2005, 320.)

Väsytyksestä toipuvaa kalaa on tarpeetonta nostaa ilmaan, mitä kuitenkin usein tehdään esimerkiksi kuvaamista varten. Mikäli kala nostetaan vedestä, tulee ilma-altistuksen olla minimaalinen. Jokainen vedestä poissa vietetty sekunti on kalalle turhaa lisärasitusta: kyse on kalan kannalta pyyntitilanteen eri vaiheiden aiheuttamasta kumulatiivisesta vaikutuksesta. Väsytyksestä toipuminen vie joka tapauksessa energiaa, vaikka kala saisikin levätä vedessä. (Joubert ym. 2020, 6.) Kalan pitäminen ilmassa ei lisää kalojen hyvinvointia, eikä myöskään helpota stressistä palautumista. Cook ym. (2015) suosittelevat vapautettaville kaloille korkeintaan $10 \mathrm{~s}$ ilma-altistusta, kun tavoitteena on mahdollisimman vähän kalaa rasittava käsittely. (Cook ym. 2015, 459.)

Mikäli kalaa ei oteta saaliiksi, vapautuksessa on huomioitava kalan kokema rasitus ja toipumiseen tarvittava aika. Pahoin väsynyttä kalaa ei kannata laskea suoraan takaisin veteen, vaan sen kannattaa antaa levätä esimerkiksi vedessä pidettävässä haavissa. Siinä kala saa hapekasta vettä kiduksiinsa, ja elimistö palautuu rasituksesta. Pahoin väsynyt kala, joka lasketaan vauhdilla takaisin veteen, on paitsi korkeammassa riskissä kuolla väsytyksen aiheuttamiin komplikaatioihin myös alttiimpi saaliiksi joutumiselle. (Brownscombe ym. 2017, 698.)

\section{Säätelyn sosiaalinen kestävyys}

Kalakannat lukeutuvat interaktiivisiin resursseihin, joiden hyödyntämisessä on huomioitava biologisten ja ekologisten piirteiden lisäksi myös sosiaalinen ulottuvuus. (Steelman \& Wallace 2001, 368.) Kyse on pitkälti osallisuudesta - mikä käsitys kalastajilla on suhteestaan pyydettäviin kaloihin, sekä kuinka vaikuttavina kalastajat pitävät voimassa olevaa 
säätelyä. Mikäli säätely koetaan esimerkiksi väärin kohdennetuksi tai epäoikeudenmukaiseksi, on todennäköisempää, etteivät kalastajat noudata sääntöjä täysin. (Page \& Radomski 2006, 175-176.)

Negatiivista suhtautumista selittää osaltaan kalastajien puutteellinen käsitys säätelystä. Mikäli kalastaja ei esimerkiksi tiedä veden lämpötilan vaikuttavan kalojen kuolleisuuteen, lämpötilaperustainen ohjaus voi näyttää perusteettomalta ja huonosti noudatettavalta säätelymekanismilta. Tiedon merkitystä säätelyn onnistumisessa voidaan lähestyä tällöin esimerkiksi kalastuskohteiden ylläpitäjien ja säätelyn tavoitteiden sekä kalastajien ja säätelyn välisen suhteen kautta. Kalastuskohteiden ylläpitäjät tarvitsevat säätelyn tueksi tietoa kalastajien suhtautumisesta säätelytoimiin, aivan kuten kalastajien on ymmärrettävä säätelyn tavoitteet ja niihin liittyvät mekanismit. (Thomas ym. 2014, 547, 553.)

Yhdeksi säätelytietoisuutta selittäväksi tekijäksi on esitetty erikoistumisen astetta: syvällisesti lajiin perehtyneet kalastajat ovat tietoisempia harrastuksensa vaikutuksesta kalakantoihin ja yleensä antavat suuremman painoarvon kestävyyteen liittyville kysymyksille. (Oh \& Ditton 2008, 557.) Luonnollisesti, pelkkä tietoisuuden lisääminen ei ole ihmeratkaisu kaikkiin säätelyongelmiin, aivan kuten valvonta ja sanktiointi eivät ole yksin korjanneet kaikkia kalastuksen ongelmakohtia. Säätelyn kokonaisvaltaisessa onnistumisessa onkin lopulta kyse ihmisten johtamisesta kohti toivottavia käyttäytymismalleja. (Hall-Arber ym. 2009, 301.)

\section{Ruunaan kosket virkistyskalastuskohteena}

Ruunaan kosket sijaitsevat Lieksanjoen yläjuoksulla. Noin $100 \mathrm{~km}$ pitkä jokialue oli 1860-luvulta alkaen merkittävä uittoreitti, jota varten joki perattiin. (Oksanen 2004, 310.) Perkuu näkyi lohikalojen elinolosuhteissa, kun lisääntymishabitaattien määrä väheni radikaalisti tai hävisi täysin. Kutusoraikot, pienpoikaskivikot ja vuolaasta virrasta monimuotoisen kosken tekevät suuret kivet olivat perkuusta kärsijöitä. (Koljonen 2011, 15-16.) Koskireitti on koskiensuojelulailla suojeltu (Koskiensuojelulaki 35/1987).

Ruunaan retkeilyalue perustettiin 1983, samana vuonna uittosäännön kumoamisen kanssa. Aluetta on kehitetty vastaamaan luonnossa liikkuvien ihmisten tarpeisiin luontoarvoja huomioiden. (Eisto 2009, 141.) Ruunaan retkeily- ja luonnonsuojelualue on valtakunnallisesti merkittävä 
kohde, jonne tehdään vuosittain yli 100 ooo käyntikertaa. Vuositasolla Ruunaalla harrastetaan kalastusta yli 10 ooo lupavuorokauden verran, ja alue on valittu myös vuoden retkeilykohteeksi. (Paulus 2019, 10.)

Lohikalakannat ovat lähes täysin istutusten varassa. Ensimmäiset istutukset tehtiin 1950-luvulla, kun Lieksanjokeen istutettiin järvilohta ja -taimenta. Alkuperäisistä lohikalakannoista vain harjus ja siika ovat luontaisesti lisääntyviä, mutta nekin ovat elinvoimaisuudeltaan mahdollisesti taantuvia. (Ruunaan HKS 2002, 12.) Taimen- ja kirjolohi-istutuksilla paitsi houkutellaan kalastajia myös kompensoidaan luontaisen lisääntymisen puuttumista. Myytävien kalastuslupien määrää ei rajoiteta aluekohtaisesti, mutta kalat ovat kiintiöityjä, jolloin saaliiksi saa ottaa vain luvan myöntämän määrän kaloja. (Eräluvat.fi, Ruunaan kosket.)

Vuoden 2020 alussa Ruunaan kalastussääntöjä uudistettiin. Uusien kalastussääntöjen mukaan vain väkäsettömät koukut on sallittu ja koukkujen kokonaismäärä on rajoitettu kolmeen. Alueella on myös syysrauhoitus ja keväinen kahluukielto. Näillä pyritään antamaan järvitaimenelle ja -lohelle syksyinen kuturauha sekä suojelemaan keväällä sorassa olevaa lohikalojen mätiä ja juuri kuoriutuneita pienpoikasia. Vuosina 2017-2019 väkäsettömyys ja koukkumäärärajoitus koskivat vain syysrauhoitusaikaa. Tätä aiemmin koukkurajoituksia ei ollut. Aineistonkeruuaikaan myytävissä kalastusluvissa, säännöissä tai eri opasteissa ei ollut huomioitu pyyntiveden lämpötilaa, haavin käyttöä eikä myöskään vapautettavien kalojen käsittelytapoja.

Säätely on muuttunut monilta keskeisiltä osin viimeisen kolmen vuoden aikana. Säätelyn kestävyyttä ja etenkin sen toimivuutta ajatellen kiintoisaa on se, kuinka kalastajat suhtautuvat säätelyyn. Tätä kysymystä tarkastellaan seuraavaksi vuorossa olevan kyselytutkimuksen toteutuksen ja metodien esittelyn jälkeen.

\section{Kyselytutkimuksen toteutus}

Keräsin tutkimusaineiston Lieksanjoen Ruunaan koskilla käyneille kalastajille kohdennetulla elektronisella kyselyllä, jossa perusjoukon muodostavat virkistyskalastuksen harrastajat. Aineistonkeruu toteutettiin 1.7.2019-30.9.2019 Webropol-alustalla. Kysymykset koostuivat monivalintakysymyksistä, symmetrisellä Likertin asteikolla olevista väittämistä sekä avoimista kysymyksistä. Tavoitteeni oli kerryttää monimuotoista 
tietoa kalastajien suhtautumisesta kalastuksen säätelyn ja pyynnin kohteena oleviin kalakantoihin.

Kyseessä on monivaiheinen otostutkimus, jossa yhdistyvät sekä mukavuus- että systemaattinen otanta. Menetelmän valintaan vaikuttivat haasteellisuus perusjoukon tavoittamisessa sekä aineistonkeruun kustannustehokkuus.

Kalastajien tavoittaminen oli ilmeinen haaste, sillä Ruunaan kaltaisessa kohteessa käyvät kalastajat ovat vaihtuva joukko. Luvanmyynnistä johtuen kaikista kalastajista ei ole mielekkäästi muodostettavissa yhtä tietuetta, joka yksinkertaistaisi aineistonkeruuta. Kalastajat ovat voineet aiemmin ostaa kalastuslupansa esimerkiksi mobiililupina, jotka on lähetetty suoraan luvanostajan matkapuhelimeen, tai luvat on ostettu Eräluvat.fi -palvelun kautta. Kalastuslupia myydään lisäksi paikallisissa myyntipisteissä Lieksassa sekä Ruunaan retkeily- ja matkailukeskuksissa. Lupaostoista muodostuu erilaisia rekistereitä, joten suunnittelin aineistonkeruun kaksivaiheiseksi.

Ensimmäisessä vaiheessa jaoin kyselyä kalastajien suosimilla alustoilla ${ }^{1}$. Aineistonkeruussa avusti myös Suomen Vapaa-ajankalastajien keskusjärjestö (SVK), jonka kautta kyselylinkkiä levitettiin SVK:n jäsenseuroille. Kyse oli vastaajien itseohjautuvuuteen perustuvasta mukavuusotannasta: kyselylinkkiä jaettiin aktiivisesti internetissä sekä yleisesti levitettynä että kalastusseurojen jäsenille valtakunnallisesti kohdennettuna. Toisessa vaiheessa aineistonkeruuta tehtiin yhteistyössä Metsähallituksen kanssa. Metsähallitus muodosti Eräluvat.fi -palvelun kautta Ruunaan kalastuslupia ostaneiden henkilöiden sähköpostiosoitteesta tietueen, jonka avulla lähetin kalastajille henkilökohtaiset kyselylinkit. Metsähallituksen tietosuojaselosteen mukaan henkilötietoja voidaan käyttää tutkimuksen tekemiseen (https://verkkokauppa.eraluvat.fi/fi/tietosuojaseloste). Tietue ei sisältänyt tarkempia henkilö- tai osoitetietoja, vaan se koostui nimenomaisesti lupia ostaneiden kalastajien sähköpostiosoitteista. Tietue poistettiin kyselyn tekemisen jälkeen. Näin aineistonkeruu muuttui systemaattiseksi otannaksi, kun yhteyttä otettiin sellaisiin kalastajiin, joiden tiedettiin kalastaneen Ruunaalla kahden viime vuoden aikana. Sähköposti lähetettiin yhteensä 1194 Ruunaan kalastusluvan ostaneelle, ja vastausprosentiksi sähköpostikyselyn osalta tuli 22,4\%.

$1<$ www.perhokalastajat.net $>,<$ www.kalamies.com>, "Kalastajat", "Perhokalastajat", "Pilkkihullut", "Koskikalastajat", "Vastuulliset kalastajat", "Itä-Suomen kalastajat" 


\section{Aineiston edustavuus}

Kyselyyn vastasi 521 henkilöä, mitä voidaan pitää määrällisesti hyvin edustavana otoksena niin yleisellä tasolla (Heikkilä 2014, 43) kuin muihin vastaaviin tutkimuksiin verrattuna. Esimerkiksi Ruunaan retkeilyalueen kävijätutkimuksen tavoitteena oli 410 vastausta (Paulus 2019, 15), mihin nähden kalastajakyselyn vastausmäärä oli neljänneksen suurempi. Luvanmyyntitilaston mukaan Ruunaalla on kalastanut kolmen viime vuoden aikana keskimäärin 5650 kalastajaa vuosittain, joten kalastajakysely tavoitti hieman alle $10 \%$ kohteessa vuositasolla käyvistä henkilöistä.

Vastaajajoukko jakautui puoliksi keruumenetelmän mukaan. Foorumeiden, sosiaalisen median ja SVK:n seuratiedotuksen kautta kyselyyn vastasi 253 henkilöä ja Metsähallituksen sähköpostitietueen kautta lähetetyt kyselyt tavoittivat 268 vastaajaa. Mikäli aineistonkeruussa olisi hyödynnetty yksin mukavuusotantaa, tulosten yleistettävyys olisi kiistanalainen, mutta systemaattinen otanta lisää selvästi aineiston luotettavuutta. (Heikkilä 2014, 39.) Aineisto ei kata kaikkia Ruunaalla käyneitä kalastajia, mutta vastausten lukumäärä ja keruumenetelmät huomioiden tulokset ovat varsin luotettavia.

Kyselyyn vastanneista 521 henkilöstä miehiä oli 505 (96,9 \%), naisia 15 $(2,9 \%)$ ja muunsukupuolisia 1 (0,2 \%). Jakauma eroaa retkeilyalueen kyselyn kävijäjakaumasta, jossa miehiä oli $57 \%$ ja naisia $43 \%$. Miesten yliedustus kertoo siitä, kuinka erilaisia eri harrastajajoukot ovat: tilastojen mukaan kalastus on edelleen miehinen harrastus. (LUKE, Vapaaajankalastuksen tilastot 2018.) Vastanneista $43 \%$ :lla oli lukio- tai ammattikoulupohja. Alempi korkeakoulututkinto oli kolmanneksella vastaajista (30 \%), ja 20 \% ilmoitti koulutustasokseen ylemmän korkeakoulututkinnon. Peruskoulun käyneitä vastaajista oli $7 \%$. Ikäjakauman osalta tyypillinen vastaaja oli $35-44$-vuotias. Paikkakuntalaisia vastaajista oli vain $7 \%$, naapurikuntalaisia $21 \%$, ja ulkopaikkakuntalaisia $72 \%$. Ulkomailla asuvia kyselyvastaajia oli kaksi.

Aineisto vastaa varsin pitkälle Ruunaan kävijätutkimuksen tulosta alueen kävijöistä (Paulus 2019, 15-16), sekä Luonnonvarakeskuksen määrittelyä virkistyskalastajista keskimääräisten sukupuoli- ja koulutusjakaumien osalta. (Pellikka \& Eskelinen 2019, 5.) Kysely vaikuttaa siis tavoittaneen "keskimääräisen Ruunaan kalastajan" suhteellisen hyvin, jolloin 
aineistonkeruutta voi pitää vastausten lukumäärän perusteella hyvin onnistuneena, ja aineistoa kohtalaisen edustavana.

\section{Käytetyt analyysimetodit}

Aineistojen analyysi jakautuu luokittavaan ja tulkitsevaan analyysiin. Luokittavassa analyysissä aineisto kategorisoidaan temaattisiin kokonaisuuksiin, jotka auttavat selventämään aineiston sisäisiä eroja. Luokitteluun sisältyy tällöin oletus, ettei aineisto ole sisällöltään homogeeninen, vaan eri ihmisiltä kerättynä aineisto sisältää yksilö- ja ryhmätason eroja. Luokittava analyysi keskittyy tällöin kysymykseen siitä, mitä eroja aineistossa oikein on. (Vesala \& Rantanen 2007, 11-12.)

Luokittelussa kysyn, mitä jakaumat kertovat kalastajien suhtautumisesta kalastuksen säätelyyn niin yleisellä tasolla kuin yksittäisten säätelytoimien kohdalla. Vastausjakaumien tunnuslukujen tarkastelussa hyödynnän kvantitatiivisia menetelmiä. Vastausten taulukoinnissa on esitetty tarkat prosentuaaliset osuudet eri väittämiin suhtautumisesta. Avoimiin kysymyksiin saadut vastaukset tukevat kvantitatiivista analyysiä tuomalla numeerisen aineiston lisäksi kuvailevaa sisältöä. Näin aineistosta on mahdollista luoda syvempi tulkinta ja tunnistaa vastaajajoukon erilaisia ominaispiirteitä. (Tuomi \& Sarajärvi 2017, 57-58.)

Voidakseen vastata mielekkäästi esitettyihin väittämiin kalastajilla on täytynyt olla jonkinlaista tietoa kalastuksen vaikutuksista, säätelystä ja kohteen kalakannasta. Analyysissa keskeistä ei ole, pitääkö kalastajien tieto absoluuttisesti paikkaansa, mutta kiintoisaa on se, millaisen käsitys kalastajilla on säätelystä. Työ kytkeytyy osaksi kalastajien tiedon tutkimusperinnettä, jossa kalastajien kokemustietoa on hyödynnetty esimerkiksi kalastuskohteiden säätelyn kehittämisessä (esim. Stead ym. 2006). Luokittelevan analyysin jälkeen tehdään tulkitseva analyysi, jossa saatuja tuloksia selitetään teoreettisten näkökulmien avulla. Tulkinnassa tarkastelen havaintoja ensisijaisesti ekologisen kestävyyden (Charles 2001), erikoistumisen (Salz \& Loomis 2005) ja kokemustiedon (Stephenson ym. 2016) kautta. 


\section{Tulokset}

Käsittelen seuraavaksi vastaajajoukon perustiedot ja jakaumat kalastustavan ja -tavoitteellisuuden sekä aktiivisuuden mukaan. Tämän jälkeen tarkastelen vastaajien suhtautumista saaliin ottamiseen, sekä kalastuksen säätelyyn. Lopuksi esittelen vastaajajoukon keskinäisiä eroavaisuuksia. Teen tämän tarkastelemalla erikseen viehe- ja perhokalastajia, ja heidän suhtautumistaan keskeisiin säätelykysymyksiin. Tällä tavoin syvennän käsitystä kyselyyn vastanneista virkistyskalastajista monimuotoisena joukkona.

\section{Vastaajajoukko}

Vastaajajoukossa painottuu kalastusta aktiivisesti harrastavien osuus. Alle 10 vuorokautta vuositasolla kalastavien satunnaiskalastajien osuus oli $12 \%$, ja 11-30 vuorokautta kalastavia oli $43 \%$. Loput $45 \%$ ilmoittavat kalastavansa vuosittain yli 30 vuorokautta. Vastaajajoukko näyttäytyykin kohtalaisen aktiivisten kalastajien ryhmänä, mikä on huomionarvoista tulosten tulkinnassa. Vuositasolla esimerkiksi 40 vuorokautta kalastavalla on todennäköisesti erilainen käsitys esimerkiksi kalaston tilasta kuin henkilöllä, joka kalastaa vain kahtena, kolmena päivänä vuodessa. Vastaajat olivat kokonaisuudessaan kokeneita: alle 10 vuotta kalastusta harrastaneita oli vain $8 \%$. Kalastusta 11-30 vuotta harrastaneita oli $45 \%$, ja loput $47 \%$ ilmoittivat harrastaneensa kalastusta yli 30 vuotta.

\section{Kalastuksen motivaatiotekijät ja tyylit}

Kategorisoin vastaajat kalastuksen motivaatiotekijöiden ja käytettyjen välineiden mukaan. Tärkeimpiä motivaatiotekijöitä olivat uusien kokemusten saaminen ja kalavesillä virkistyminen (79\%), ja toissijaisesti kalojen pyytämisen omaksi tai perheen ravinnoksi (14\%). Avointen vastausten kohdalla loput 7 \% ilmoittivat tärkeimmiksi tekijöiksi pääasiassa luontokokemukset, joihin osa vastaajista laski myös itse pyydetyn kalan syömisen. Jakauma vastaa aiempaa tutkimusta vapaa-ajankalastajien motivaatiotekijöistä. (Toivonen ym. 2003, 5.)

Vastaajista viehekalastajia oli $41 \%(n=215)$ ja perhokalastajia $59 \%$ $(\mathrm{n}=306)$. Kysely tavoittikin hyvin molempien lajien harrastajia. Jaon viehe- ja perhokalastajiin tein tarkemmin kalastajatyyppien 
kategorisoinnin vuoksi, sillä kalastussääntöjen rajoitusten osalta harrastajaryhmät poikkeavat osin toisistaan: yksittäinen sääntö voi koskettaa käytännössä enemmän toista kalastajaryhmää.

\section{Ruunaalla harrastettavan kalastuksen määrä}

Vastaajat kalastavat Ruunaalla kohtalaisen säännöllisesti. Harvemmin kuin joka vuosi kävi $41 \%$ vastaajista, 51 \% ilmoitti kalastavansa Ruunaalla vuosittain, ja 8 \% kävi joko kuukausittain tai viikoittain. Viimeisen viiden vuoden aikana Ruunaalla oli käynyt vastaajista yhteensä $94 \%$. Viive kalastussääntöjen päivittämisen ja edellisen käynnin ajankohtien välillä tuli esiin avoimissa vastauksissa, kun osa vastaajista toivoi kalastukseen sellaisia sääntöjä, jotka on saatettu voimaan viimeisen kahden vuoden aikana. Enemmistö (88 \%) vastaajista ilmoitti kalastavansa Ruunaalla 1-10 vuorokautta vuodessa, $8 \%$ kalasti 11-20 vuorokautta, ja loput $4 \%$ kalastivat tätä enemmän. Vuorokausimäärää ja käyntien säännöllisyyttä ajatellen tyypillinen vastaaja kalastanee Ruunaalla kesäsesongin aikaan muutaman viikonloppureissun verran.

\section{Suhtautuminen saaliin ottamiseen}

Hienoinen enemmistö (56 \%) ilmoitti parhaiten omaa kalastusta kuvaavaksi määritelmäksi valikoivan kalastuksen. Ensisijaisesti ruokakalaa pyytäviä oli $32 \%$ ja pyydystä ja päästä -kalastajia $12 \%$. Valikoivassa kalastuksessa vapautetaan myös alamitan ylittäviä, ruoaksi kelpaavia saaliskaloja, ja saaliiksi pyritään saamaan tiettyyn lajiin kuuluva tai tietyn kokoinen yksilö. Tavoitteena on keskittyä kaloihin, joiden pyytäminen aiheuttaa vähiten vahinkoa kyseiselle populaatiolle tai jotka muuten ovat kalastajalle mieluisimpia kaloja ravinnoksi. Jakaumat osoittavat, kuinka Ruunaalla kalastavat henkilöt eivät ole homogeeninen joukko, jota ohjaisi yksin ruokakalan saaminen tai pelkkä elämyksellinen pyynti. Kalastajien tavoitteiden, motivaatiotekijöiden ja kalastukseen liittyvien arvojen moninaisuus on huomionarvoinen tekijä kohteen kalastusjärjestelyitä suunniteltaessa. 


\section{Kalastajien suhtautumisesta kalastuksen säätelyyn}

Kaaviossa 1 on esiteltynä vastausjakaumat keskeisimpiin kalastuskuolleisuuteen ja kalojen hyvinvointiin vaikuttaviin tekijöihin.

\section{Kaavio 1. Kalastajien suhtautuminen keskeisiin säätelytoimiin}

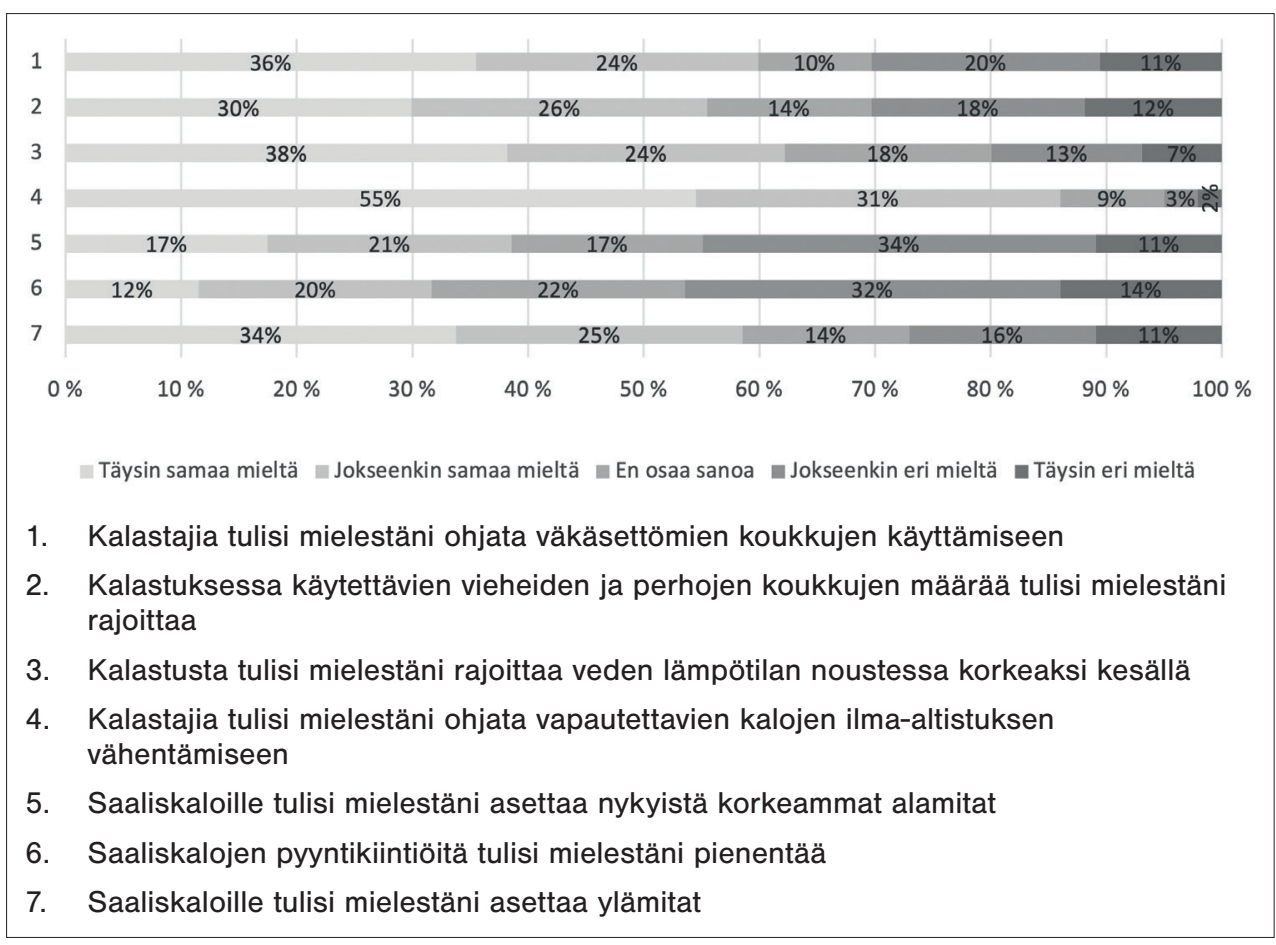

Kaavio 1 osoittaa varsin selviä jakaumia säätelykysymyksiin liittyen. Väkäsettömien koukkujen käyttäminen, ilma-altistuksen vähentäminen ja pyynnin rajoittaminen liian lämpimän veden aikaan saavat vähintään 60 \% kannatuksen. Koukkujen määrän rajoittamisen kannalla oli $56 \%$ vastaajista. Tämän perusteella säännöt koukkujen väkäsettömyyteen ja määrän rajoittamiseen liittyen vaikuttavat nauttivan suhteellisen korkeaa suosiota.

Säätelyn kehittämiselle on huomionarvoista, että niin ilma-altistuksen vähentäminen kuin pyynnin rajoittaminen korkean veden lämpötilan aikaan vaikuttavat olevan toivottuja toimia. Ilma-altistuksen välttämisen kannalla oli 86 \% vastaajista, ja liian lämpimän veden aikaan kalastusta olisi valmiit rajoittamaan $62 \%$. Molemmat osa-alueet puuttuvat täysin 
nykyisestä säätelystä. Vaikka ilma-altistusta ei voida valvoa samalla tavalla kuin esimerkiksi veden lämpötilaa tai käytettävien koukkujen väkäsiä, asiaan voidaan kuitenkin vaikuttaa tietoisuuden lisäämisellä. Tulos havainnollistaakin osaltaan säätelyssä olevaa kestävyysvajetta, mutta etenkin kalastajien halukkuutta vajeen poistamiseen.

Alamittojen korottaminen tai pyyntikiintiöiden pienentäminen eivät saaneet kovin selvää kannatusta tai vastustusta, joten nykytilanteeseen vaikutetaan olevan näiltä osin kohtuullisen tyytyväisiä. Korkeampien alamittojen puolella oli $38 \%$ vastanneista ja vastaan $45 \%$. Samoin pyyntikiintiöiden pienentämisen puolella oli vain $32 \%$ ja pienentämistä vastaan $46 \%$. Vastaavasti ylämittojen puolella vastaajista oli $59 \%$ ja vastaan 27 $\%$.

Avoimeen mielipidekysymykseen säätelyn nykytilasta vastasi 165 kalastajaa. Vastauksissa nousi useimmin esiin harjus (22 mainintaa) ja taimen (18 mainintaa), joiden kohdalla toivottiin useimmin rauhoittamista, tiukempaa kiintiötä tai korkeampia alamittoja. Pyydystä ja päästä -kalastus oli ilmeisen kaksijakoinen: se nähtiin toisaalta nykyaikaisena, kalakantoja säästävänä toimintana, mutta yhtäältä sen koettiin olevan pelkästään turhaa stressin aiheuttamista kaloille. Vastauksissa kilpailivat perinteinen ajatus kalasta ihmisravintona ja kaloista virkistyksen lähteenä.

Ehkä tähän CR kalastukseen olisi syytä kehittää jotain "ohjattua moraalista CR kiintiötä" myös varsinaisen saaliskiintiön rinnalle.

Säätelystä toivottiin vastauksissa yksinkertaisempaa, jolloin samat säännöt pätevät koko jokialueella. Asia liittynee aiempiin väkäsettömyysja koukkumäärärajoituksiin pelkän syysrauhoituksen aikaan. Toisaalta myös alueen koko ja monimuotoisuus tunnustettiin: esimerkiksi koskireitin yläosia toivottiin tiukemmin säädellyiksi alueiksi, jolloin ensisijainen ruokakalojen pyytäminen keskittyisi alemmille koskille.

Ruunaan tulisi jatkossa keskittyä taimenkannan elvyttämiseen kuitenkin niin, että monelle kalastajalle tärkeät ruokakalatkin olisi saatavissa. Osa koskista voitaisiin pyhittää c\&r kalastukselle ja toiset 'ruokakalapaikoiksi'.

Kahluukieltoja pidettiin varsin laajalti toimimattomina, koska Ruunaalla ei koettu olevan vielä sellaisia habitaatteja, joihin kahlaamalla voitaisiin aiheuttaa vahinkoa kaloille. Osa vastaajista koki säätelyn lisäksi hyvinkin kaksijakoisena: toisaalta hyvällä säätelyllä turvataan kalakantoja, mutta vaellusyhteyden ja lisääntymisympäristöjen puuttuessa tiukempi säätely 
nähtiin jopa pikkumaisena toimintana, jolla ei lopulta puututa ekosysteemin todellisiin ongelmiin.

Lisää tiukennuksia ja jää kalastus kokonaan väliin. Nykyiselläänkin hommasta alkaa mennä mielekkyys. Niin kauan kun joki-uomassa on yksikin patoava voimalaitos, ei ole oikein kiusata vapaa-ajan kalastajia. vapa-kalastajat eivät kaloja sukupuuttoon tapa!

Vastauksissa nousi esiin huomio säätelyn tavoitteista ja noudattamisesta. Vastaajien mukaan jo nykyiset säännöt itsessään antaisivat mahdollisuuden paljon nykyistä parempaan tilanteeseen, mutta sääntöjä rikotaan varsin paljon - niin tietoisesti kuin tietämättömyyden takia. Osa kertoi kalastaneensa kohteessa vuosien ajan edes näkemättä valvojaa. Valvonnan vähäisyys on rakenteellinen ongelma, joka etenee suoran signaalin tavoin jokivarressa: puutteellinen valvonta tiedostetaan, ja sääntöjä rikkovat henkilöt hyödyntävät puutetta.

Yhtäältä on kiistatonta, että kaikki sääntöjä rikkovat eivät toimi näin pelkästä välinpitämättömyydestä, vaan osa toiminnasta selittyy puutteellisilla tiedoilla. Vuotuiset kalastajamäärät huomioiden ei ole perusteltua olettaa kaikkien hallitsevan esimerkiksi asiallista kalojen käsittelyä. Kuten eräässä vastauksessa todettiin:

Olisin kaivannut tietoa miltä näyttää leikattu rasvaevä ja miltä leikkaamaton. Siinä tilanteessa kun kala on maalla niin on vähän paha ruveta etsimään verrokkikuvia netistä.

Lopuksi kalastajat saivat arvioida kalastuksen ja sen säätelyn kestävyysja tietokysymyksiä. Vastausjakaumat ovat esiteltynä kaaviossa 2.

Vastaajista 73 \% koki kalastussääntöjen olevan kestävästi suunniteltuja, joten tiedostetuista puutteista huolimatta yleiskäsitys säätelyn nykytilasta oli myönteinen. Kestävyyskäsitystä tukee myös se, että 66 \% vastanneista koki säätelyn vastaavan nykyaikaista tietoa kalakannoista ja niiden kestävästä pyytämisestä. Jakaumat kertovat siitä, että puutteista huolimatta säätely koetaan periaatetasolla varsin toimivaksi. Kiintoisaa jakaumissa on tietoperustaisen ohjauksen tarve, jonka kannalla oli $75 \%$ vastanneista.

Tulos on merkityksellinen erityisesti kalastuksen säätelyn kehittämiselle. Säätelyä ei ilmeisesti koeta vielä liialliseksi, jolloin mahdolliselle lisäohjaukselle on tilaa. On syytä huomata, että kyse ei ole yksin kielloista, vaan 
Kaavio 2. Kalastajien suhtautuminen kestävyys- ja tietokysymyksiin

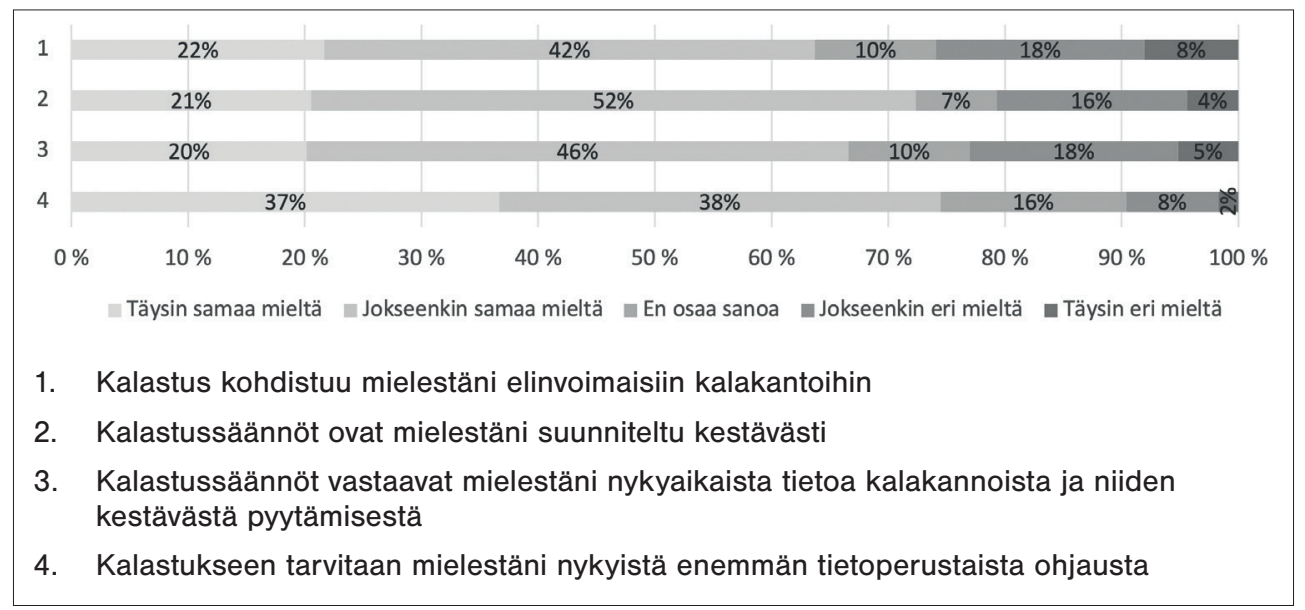

ohjausmenetelmiä voivat olla myös suositukset kaloille suotuisaan toimintaan. Toimintaa voidaan ohjata yksinkertaisimmillaan opasteilla, jolloin kyse on parhaiden käytäntöjen juurruttamisesta osaksi alueen kalastuskulttuuria tietoisuutta lisäämällä. (Joubert ym. 2020, 6.) Ruunaan kalastajamäärät huomioiden ei ole realistista olettaa, että kaikki kohteeseen saapuvat kalastajat hallitsevat kalojen asiallisen käsittelyn, vaan ohjaukselle on perusteltu tarve. Kuten yksi vastaajista totesi, säätelytoimien, niistä tiedottamisen ja sääntöjen noudattamisen välillä on haasteita.

\footnotetext{
Lupamyyntinettisivu on todella sekava ja jotain pohjatietoa pitää kestävästä kalastuksesta olla, että sieltä osaa säännöt etsiä. Ei ne säännöt mitenkään silmillä pomppaa. Ei netissä eikä paikan päällä. Esimerkiksi kahlaamiskielto ei tunnu vaikuttavan mitenkään.
}

Tulosten kenties ristiriitaisin jakauma liittyy kalakantojen elinvoimaisuuteen: 64 \% koki kalastuksen kohdentuvan elinvoimaisiin kalakantoihin. Kun kalastajilta kysyttiin mitä kalalajeja he mieluiten pyytävät, ravinnoksi pyydettävistä halutuin oli kirjolohi (83 \%) ja elämyksellisistä syistä pyydettiin mieluiten järvitaimenta (47\%). Kirjolohi on Suomen luontoon kuulumaton vieraslaji, jonka esiintyminen perustuu yksin istutuksiin. Vastaavasti järvitaimen on ollut Ruunaalla luontainen laji, mutta menetettyjen habitaattien johdosta taimen on käytännössä täysin istutusten varassa. Nämä seikat huomioiden elinvoimaisuuskäsitys on erikoinen, sillä lohikalojen kalastus kohdentuu pääasiassa keinotekoisiin kantoihin. 
Kun tarkastellaan lähemmin sitä vastaajajoukkoa $(n=332)$, jossa kalastuksen koettiin kohdentuvan elinvoimaisiin kalakantoihin, enemmistö (90 \%) piti itseään virkistyskalastajina. Suurimmalla osalla (75 \%) vapaaajankalastuksen tärkein vetovoimatekijä oli uusien kokemusten saaminen ja kalavesillä virkistyminen. Yli puolet (54 \%) ilmoitti harrastavansa Ruunaalla valikoivaa kalastusta, ruokakalan pyytämisen (36\%) sekä pyydystä ja päästä -kalastuksen (10 \%) ollessa vähemmän merkityksellisiä. Vastaajat vaikuttavatkin keskiverroilta virkistyskalastajilta. Merkillepantavaa on kuitenkin se, että kyselylomakkeen spesifeissä järvitaimeneen liittyvissä kysymyksissä $17 \%$ piti Ruunaan järvitaimenkantaa elinvoimaisena, ainoastaan $5 \%$ uskoi sen selviävän ilman istutuksia, ja vain $20 \%$ koki taimenkannan kestävän nykyisen pyyntipaineen.

Tulosten perusteella voidaan kiistatta todeta, että kalastajien käsityksissä on ristiriitaisuutta. Vaikka pyydettävän taimenkannan elinvoimaisuuteen ei selvästikään uskota, kalastuksen kokonaisuudessaan nähdään keskittyvän pääasiallisesti elinvoimaisiin kantoihin. Kyselyssä ei annettu elinvoimaisuudelle kriteeristöä tai määritelmää, jota vastaajien olisi noudatettava arvioitaessa pyydettävien kalakantojen tilaa, joten tulos heijastaa nimenomaisesti kalastajien omaa käsitystä. Osaselityksen voi tarjota kirjolohen suosio ruokakaloja pyydettäessä, jolloin kestävyyskysymys ei nouse merkittäväksi tekijäksi.

Ilmiötä on kokonaisuudessaan mahdotonta selittää täydellisesti nykyisellä aineistolla, mutta se herättää perustellun kysymyksen siitä, kuinka kokonaisvaltaisesti kalastajat pystyvät arvioimaan kalastuksen vaikuttavuutta ja kalastuskohteen ekosysteemistä tilaa. Ristiriita kertoo osaltaan siitä, että kalastajat ilmeisesti pystyvät arvioimaan jopa suhteellisen tarkasti yksittäisten kalalajien tilannetta, mutta holistisessa arviossa kokonaiskuva vinoutuu.

\section{Perhokalastajien ja viehekalastajien eroavaisuuksista}

Kalastajaryhmien erottelun tarkoitus on syventää tietämystä virkistyskalastajista heterogeenisenä joukkona. Kyselyyn vastanneista perhokalastajia oli $59 \%(n=306)$ ja viehekalastajia $41 \%(n=215)$. Perho- ja viehekalastajien motiivipohja on pitkälti samankaltainen: vastaajat pitävät itseään yleisellä tasolla eniten virkistyskalastajina, joille virkistäytyminen ja uusien kokemusten saaminen on pelkkää ruokakalan pyytämistä merkityksellisempää. 
Tarkasteltaessa lähemmin Ruunaalla harrastettavaa kalastusta hienoinen enemmistö niin perhokalastajista (59 \%) kuin viehekalastajista (51 \%) ilmoittaa harrastavansa valikoivaa kalastusta. Viehekalastajissa ensisijaisesti ruokakalaa pyytävien osuus (42\%) on kuitenkin selvästi perhokalastajien vastaavaa osuutta (25\%) suurempi. Vastaavasti pyydystä-ja-päästä -kalastus on perhokalastajilla (16 \%) yleisempää kuin viehekalastajilla (7 \%.) Ryhmien välillä ei ole merkittävää eroavaisuutta kalastusharrastuksen kokonaiskestossa tai vuositason kalastusmäärissä. Kaaviossa 3 on esiteltynä säätelykysymyksiin suhtautuminen kalastajaryhmittäin.

Jakaumien perusteella perhokalastajat olivat varsin selvästi viehekalastajia myöntyväisempiä erilaisiin rajoitus- ja säätelytoimiin. Etenkin koukkujen väkäsettömyydessä ja koukkumäärien rajoittamisessa sekä kalastuksen välttämisessä liian lämpimän veden aikaan perhokalastajat näyttävät suhtautuvan rajoituksiin selvästi viehekalastajia suotuisammin.

Korkeammissa alamitoissa ja ylämittasäädöksissä erot tasoittuvat hieman, mutta myös näissä perhokalastajat suhtautuivat viehekalastajia myönteisemmin esitettyihin rajoitusvaihtoehtoihin. Viehekalastajille selvästi kielteisin rajoitusvaihtoehto oli kiintiöiden pienentäminen. Kaikkein lähimpänä toisiaan kalastajat vaikuttavat olevan ilma-altistuksen vähentämisessä, jonka puolella on selvä enemmistö molemmissa ryhmissä.

Aineisto ei mahdollista aukotonta vastaamista jakaumien eroihin, mutta aihetta voi lähestyä muun muassa kalastusvälineiden ja -strategioiden kautta. Perhokalastuksessa käytetään nykyisin jo varsin laajalti yksihaaraisiin koukkuihin sidottuja perhoja, joiden määrä on useissa kohteissa rajoitettu kahteen tai kolmeen. Perhokalastajalle koukkujen maksimimäärän rajoittaminen nykyisten sääntöjen mukaisesti kolmeen ei tarkoita välttämättä mitään konkreettista muutosta.

Sen sijaan viehekalastaja voi joutua poistamaan uusien sääntöjen mukaan vieheestään yhdestä kahteen kolmihaarakoukkua, mikä voidaan kokea pyyntivälineen tehon heikkenemiseksi ja siten epämieluisaksi säätelytoimeksi. Kun lisäksi huomioidaan, että viehekalastajista suuri osa on ruokakalan pyytäjiä, mahdollinen kokemus pyyntivälineen tehon heikkenemisestä olisi looginen selitys kielteiseen suhtautumiseen. Samoin pyyntikiintiön pienentäminen osuu vahvimmin juuri ruokakalojen pyytäjiin. 
Kaavio 3. Perho- ja viehekalastajien suhtautuminen säätelykysymyksiin

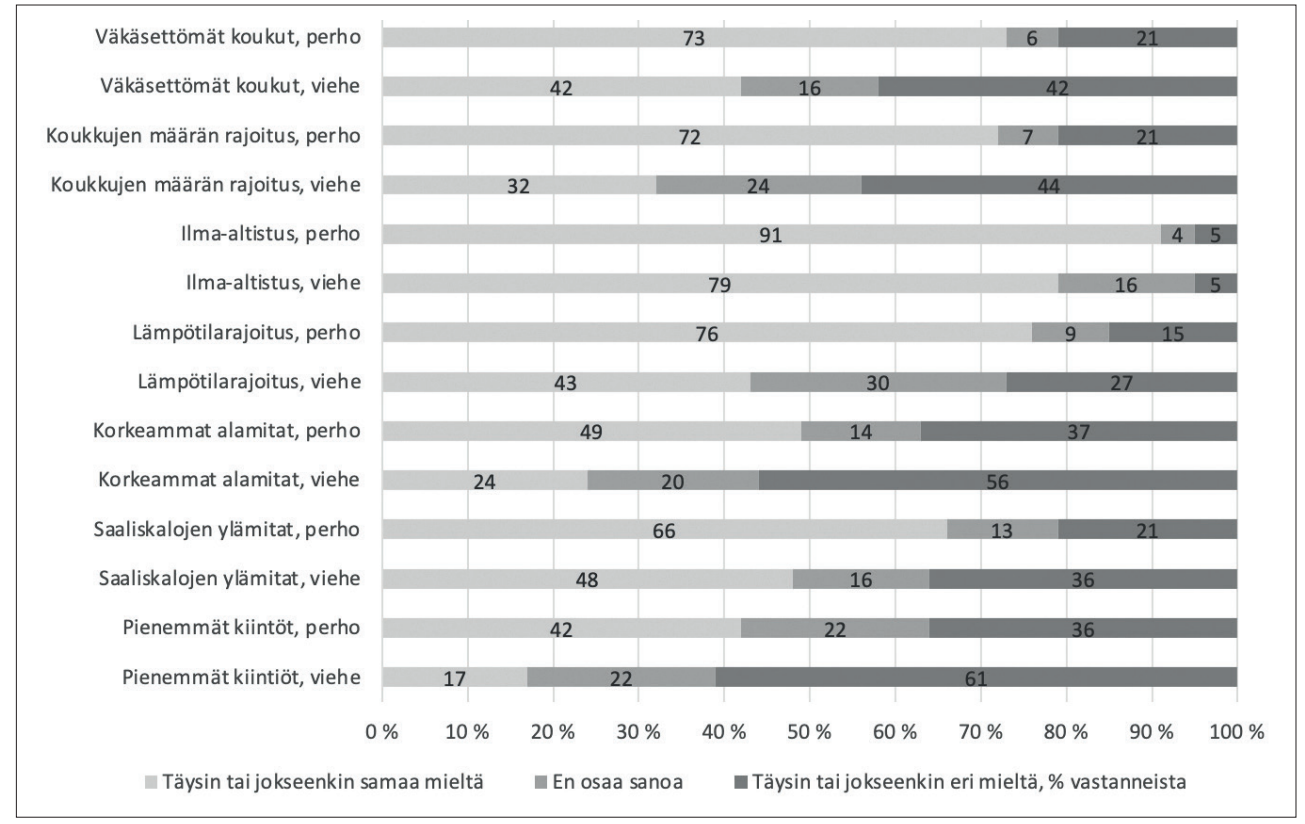

Toinen huomionarvoinen piirre jakaumissa liittyy perhokalastajien jyrkempään joko-tai -jakautumiseen, sillä "en osaa sanoa" vaihtoehtoja on valittu selvästi viehekalastajia vähemmän. Kuten kuva 4 (seur. sivulla) havainnollistaa, kaikkien säätelykysymysten vastausten keskiarvoissa viehekalastajien "en osaa sanoa" valintojen osuus on kaksinkertainen perhokalastajiin verrattuna. Vaikuttaakin siltä, että perhokalastajilla on varsin selvästi viehekalastajia vahvempi mielipide eri säätelykysymyksiin.

On mahdollista, että perhokalastajat ovat keskustelleet säätelyyn liittyvistä kysymyksistä enemmän esimerkiksi harrastelehdissä tai muussa mediassa, jolloin tietoisuus säätelytoimien tavoitteiden tai vaikuttavuuden osalta on korkeampi.

Yhteenvetona perho- ja viehekalastajien eroavaisuuksista voidaan todeta, että perhokalastajat ovat viehekalastajia valmiimpia rajoittamaan käytettyjä välineitä sekä asettamaan tiukempia rajoituksia kalastukselle. Tuloksen perusteella ei kuitenkaan voida aukottomasti väittää, että perhokalastajat olisivat kategorisesti tiukempia tai vastuullisempia kalastuksen säätelyn suhteen, sillä viehekalastajille leimallista olivat paikoitellen yllättävän suuret "en osaa sanoa" osuudet. 
Kaavio 4. Keskiarvot perho- ja viehekalastajien suhtautumisesta keskeisiin säätelykysymyksiin

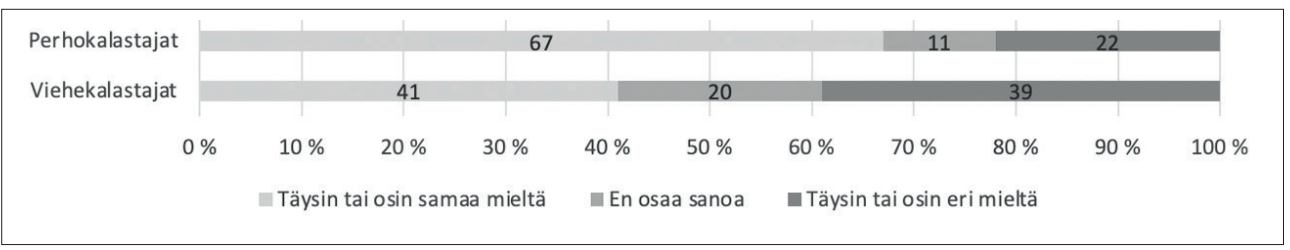

Esimerkiksi pyyntiveden lämpötilaa käsitelleessä kysymyksessä viehekalastajista peräti kolmannes valitsi "en osaa sanoa" -vaihtoehdon. Tulos herättääkin perustellun kysymyksen siitä, missä määrin viehekalastajilla on ollut tietoa käytettävien välineiden vaikutuksista tai yleensä kalastuskuolleisuuteen vaikuttavista tekijöistä. Eroavaisuuksistaan huolimatta kalastajaryhmillä oli myös yhdistäviä piirteitä, joista kaikkein vahvin oli jaettu näkemys lisäohjauksen tarpeesta. Molemmissa vastaajaryhmissä selvä enemmistö oli tietoperustaisen ohjauksen kannalla: perhokalastajista $78 \%$ ja viehekalastajista $69 \%$ koki lisäohjauksen tarpeelliseksi.

\section{Kalastajien ja säätelyn monimuotoinen suhde}

Säätelykysymyksiin suhtautuminen on monitahoinen kokonaisuus, johon liittyy niin kalastajien yleistietoa, omakohtaista kokemusta ja arvoja kuin myös epävarmuuksia. (Murphy Jr. ym. 2019, 2.) Tulosten lopullisessa tulkinnassa on huomioitava, että suhtautuminen säätelykysymyksin ei aina korreloi sen kanssa, miten kalastustilanteessa toimitaan. Asenteet antavat signaalin siitä, kuinka yksilö kokee tarkastelemansa asian, mutta ne eivät kuitenkaan välttämättä sanele toimintaa. (de Houwer ym. 2013, 253.)

Tulokset kertovat säätelyn toimivuudesta mutta myös kestävyysvajeesta. Boonstra ym. ovat kategorisoineet kalastajien säätelysuhtautumisen sitoutumiseen, vastustamiseen, luovuuteen ja vastahakoisuuteen (Boonstra ym. 2017, 685-686). Luokitus havainnollistaa, kuinka säätelyyn ja ohjaustoimiin asennoituminen on monitasoisempi kokonaisuus kuin pelkkä hyväksymiseen tai vastustamiseen perustuva jako.

Lähtökohta säätelyn kestävyyden ja kehittämisen tarkastelussa on nykyisen säätelyn nauttima hyväksyntä: 73 \% piti sääntöjä kestävinä ja 66 \% näki sääntöjen vastaavan nykyaikaista tietoa. Havainto on suotuisa, sillä säätelyn yleinen hyväksyntä tukee sen noudattamista ja siten vahvistaa toiminnan kestävyyttä. (Boonstra ym. 2017, 692-693.) 
Säätelysuhtautumisen takana on panos-tuotos -suhde, jossa kalastaja joutuu arvioimaan, saako hän itselleen enemmän hyötyä noudattamalla vai rikkomalla tai muulla tavoin kiertämällä sääntöjä. Lisäksi vaihtoehtona on siirtyminen kokonaan toiseen kalastuskohteeseen.

Jakaumat osoittivat, että vastaajista ilma-altistuksen välttämisen kannalla oli $86 \%$ ja kalastuksen rajoittamisen puolella liian lämpimän veden aikaan 62 \%. Molemmat toimenpiteet puuttuivat alueen kalastussäännöistä aineistonkeruuaikana, ja jos niiden lisäämiseen päädytään, siihen tarvitaan erilaisia mekanismeja. Siinä missä pyyntiveden lämpötila on mitattavissa ja standardisoitavissa koko koskialueelle, vapautettavien kalojen käsittelyä on vaikeampi kategorisoida yksiselitteiseksi säännöksi.

Saaliskiintiöiden pienentäminen ja korkeammat alamitat näyttävät vähiten halutuilta vaihtoehdoilta, mikä on ymmärrettävää kalastajien näkökulmasta, joskin asiaan liittyy kestävyystekijöitä. Kiintiöiden pienentäminen johtaisi oletettavasti pienempään kalastuskuolleisuuteen, kun ostettua lupaa vastaan saadaan ottaa vähemmän kaloja ruoaksi. Vaikutus on kaloille suotuisa, mutta kalastajat maksaisivat suhteessa enemmän saaliiksi otettavista kaloista, mikä selittänee osan vastahakoisuudesta. Korkeammilla alamitoilla turvattaisiin tehokkaammin kalojen lisääntymistä, mutta kalastajat joutuisivat valikoimaan saalistaan nykyistä enemmän ainakin hetkellisesti. (Ayllón ym. 2019, 50.)

Ekologista kestävyyttä ajatellen riittävän korkeat alamitat yhdistettynä ylämittoihin olisivat todennäköisesti paras vaihtoehto, jolloin pyynti keskittyisi välimitan mukaisiin yksilöihin. Tällöin riittävät alamitat varmistaisivat, että saaliiksi päätyvät kalat ovat kuteneet ainakin kerran, mitä voidaan pitää ekologisesti kestävän säätelyn ehdottomana kulmakivenä. Vastaavasti ylämittojen avulla suojellaan lajinsa suurimpia yksilöitä, jotka ovat tärkeitä lisääntymiselle, mutta osaltaan myös kalastuskohteiden houkuttelevuudelle. (Esim. Ayllón ym. 2019.)

Säätelyn kiristämisessä on kuitenkin aina luontainen riski, että kalastajat kokevat säännöt liian tiukoiksi. Tällöin uudet säännöt johtavat mahdollisesti pienempään kalastajien määrään ja pienempiin lupatuloihin. (Murphy Jr. ym. 2019, 11.) Etenkin perusteettomaksi koetussa säätelyssä ongelmaksi voi muodostua myös kalastajien välinpitämättömyys - vaikka kalastuskohdetta ei vaihdettaisi toiseksi, uusia sääntöjä ei yksinkertaisesti noudateta. Sääntöjen vaikutusten arvioinnissa keskiöön nouseekin 
kalastuskohteen ja siellä liikkuvien kalastajien heterogeenisyyden tuntemus. (Knoche \& Lupi 2016, 170.)

Jakaumat osoittavat, että kalastajat eivät ole homogeeninen joukko. Kuten Nguyen ym. (2013) toteavat, yksi vesialue eri kalalajeineen mahdollistaa erilaisten kalastajaryhmien rinnakkaiselon. Eri ryhmien tavoitteet ja erikoistumisen muodot johtavat osaltaan erilaiseen suhtautumiseen säätelykysymyksiin. Esimerkiksi tietyn kalalajin - pääasiassa elämykselliseen - pyytämiseen erikoistuneet kalastajat suhtautuvat todennäköisesti myötämielisemmin tiukempaan säätelyyn, mikäli sen koetaan lisäävän itselle mieluisten kalojen määrää. (Esim. Hobson 2000.)

Eroavaisuudet näkyvät myös Ruunaalla. Perhokalastajissa oli viehekalastajia enemmän pyydystä-ja-päästä-kalastajia sekä valikoivia kalastajia. Viehekalastajille yleisempää oli sekä ruokakalan pyytäminen että nuivempi suhtautuminen rajoituksiin. Aas ym. (2000) havaitsivat perhokalastajien olleen viehekalastajia myötämielisempiä tiukempaa kalastuksen säätelyä kohtaan. Selitys oli, että perhokalastajat kokevat tiukempien sääntöjen johtavan heille mieluisampaan lopputulokseen muun muassa pyydettävien kalojen koon osalta. (Aas ym. 2000, 948.) Ruunaan tulokset vahvistavat havaintopohjaa perhokalastajien myönteisestä suhtautumisesta tiukempaan säätelyyn, mutta mekanismi säätelysuhtautumisen takana ei avaudu täysin käytettävissä olleella aineistolla.

Suhtautuminen tiukempaan säätelyyn voi olla nuivempaa kaloja pääasiallisesti ravinnoksi pyydettäessä, mikäli kalastajat kokevat oman saaliinsa vaikutuksen olevan vähäinen kalojen kokemaan kokonaiskuolleisuuteen tai laajempiin ekologisiin ongelmiin verrattuna. (Nguyen ym. 2013, 861.) Tämä näkyi avoimissa vastauksissa, kun osa kalastajista suhtautui kriittisesti uusiin rajoituksiin sillä perusteella, että kalojen vaellusyhteys Pieliselle puuttuu edelleen, eikä jokea ole entisöity luonnontilaiseksi. Säännöistä riippumatta kyse on pitkälti istutettujen kalojen pyytämisestä. Yhtäältä kyse on myös kalastajan saamasta tuotosta - maksettua lupaa vastaan halutaan saada kalaa, ja saaliin määrästä tinkiminen on vastoin kalastajan omia tavoitteita.

Säätelyn kehittämisessä kyse onkin lopulta eräänlaisesta vaihtokaupasta eri strategioiden välillä. Alamittojen kasvattaminen, ylämittojen asettaminen ja kiintiöiden pienentäminen auttavat kalakantojen suojelussa, mutta toimenpiteinä ne heijastuvat suoraan myös ruokakalojen pyytämiseen. (Gwinn ym. 2015, 268.) Kalastuskohteen ylläpitäjän pohdittavaksi 
jää tällöin se, kuinka paljon säätelyä tarvitaan esimerkiksi luontaisesti lisääntyvien kalakantojen saavuttamiseksi tai jo olemassa olevien populaatioiden suojelemiseksi, sekä millainen määrä säätelyä koetaan kalastajien keskuudessa liialliseksi, jolloin kalastuskohteen suosio laskee.

\section{Kokemustiedon hyödyntämisen mahdollisuudet}

Aineisto havainnollistaa hyvin kokemustiedon, ekologisen tiedon ja kalastuksen säätelyn välistä yhteyttä. Kokemustietoa voidaan hyödyntää luonnon prosesseihin ja säätelyyn liittyvissä kysymyksissä. (Stead ym. 2006, 78.) Tulosten perusteella kalastajat omaavat kohtalaisen hyvää tietoa kohteen kalastosta, sekä kalastuksen vaikutuksesta pyynnin kohteena oleville kalakannoille. Kenties merkityksellisin tieto liittyi asioihin, jotka eivät muuten ole kaikkein selvimmin esillä.

Ruunaalla nousi esiin huoli kohteen harjuskantoihin liittyen, joiden koettiin heikentyneen. Vuonna 2018 aloitetuissa lisääntymisympäristöjen kunnostuksissa ei huomioida harjusta, vaan kohteena ovat järvilohi ja -taimen. (Eräluvat.fi, 29.11.2019.) Samoin vastaajien huomiot niin tietoisesti kuin vahingossa tehdyistä kalastusrikkomuksista kertovat siitä, että kalastus edellyttää enemmän ohjausta ja valvontaa. Kokemustiedon puutteista huolimatta vesiltä saadun informaation avulla pystytään keräämään aineistoa säätelyn tueksi. Kalakantaa hyödyntävät kalastajat kokevat suoraan esimerkiksi kantojen heikkenemisen. (Hind 2015, 352.)

Kokemustietoa tulee kuitenkin käsitellä nimenomaisesti kokemustietona. Aineiston mukaan osa kalastajista koki pelkästään istutusten varassa olevien kalakantojen olevan elinvoimaisia, mitä voidaan pitää vahvana ristiriitana kokemusten ja tosiasiallisen tilanteen välillä. Asetelma havainnollistaa hyvin sen, että vaikka valtaosa vastaajista kokisi luonnon tai kalakannan tilan olevan tietyn tyyppinen, kokemustieto täytyy kontekstualisoida ekologista tietoa vasten. Kokemus- ja tutkimustieto eivät ole kuitenkaan tästäkään huolimatta pelkkä dikotomia, vaan parhaimmillaan ne ovat toisiaan täydentäviä. Optimitilanteessa kokemustietoa voidaan hyödyntää kalakantojen tarkkailussa tai toiminnallisten epäkohtien löytämisessä. (Stephenson ym. 2016, 1460-1461.)

Mikäli kokemustietoa halutaan hyödyntää, se edellyttää kuitenkin hyvin suunniteltua strategiaa sille, millä tavalla kalastajia kuullaan ja millä tavalla saatua tietoa hyödynnetään. Metsähallitus pyytää kalastajia 
raportoimaan muun muassa saaliiksi saaduista eväleikkaamattomista taimenista, mutta kokonaisuutta ajatellen tiedonkeruumenetelmät ovat edelleen verrattain vaatimattomat. Yhtäältä kysymys on käytössä olevista resursseista, joita kerättävän aineiston käsittely edellyttäisi.

Yhteenvetona voidaan todeta, että tulokset kertovat säätelyn toimivuudesta ja kestävyysvajeesta, mutta ne osoittavat myös kalastajaryhmien eroavaisuuksia. Tulokset antavatkin kalastuskohteen ylläpitäjälle mahdollisuuden kehittää säätelytoimia aiempaa kokonaisvaltaisemmin. Vastausten perusteella voidaan olettaa, että vuoden 2020 alussa voimaan tulleet säännöt niin väkäsettömyyden kuin koukkumäärien osalta hyväksytään kalastajien keskuudessa varsin hyvin, etenkin jos uusien sääntöjen tarve perustellaan onnistuneesti kalastajille. (Gambino ym. 2003, 40.)

\section{Kohti kestävämpää virkistyskalastusta}

Kalastuksen säätely Ruunaalla vaikuttaa tietoperustaisuudeltaan kohtalaisen hyvältä ja tulosten perusteella varsin laajasti kalastajien hyväksymältä. Vuoden 2020 alussa voimaan tulleet säännöt, joilla koukkujen määrä rajoitetaan kolmeen ja vain väkäsettömät koukut ovat sallittuja, vahvistavat konkreettisesti säätelyn kestävyyttä. Kalastajat suhtautuvat väkäsettömyyteen ja koukkujen määrän rajoittamiseen kohtalaisen myönteisesti. Tulosten perusteella mahdollinen alamittojen nostaminen ei vaikuta kovin toivotulta muutokselta. Vastaavasti saaliskalojen ylämittoja ei mainita säännöissä edes suosituksina, mutta kyselytuloksiin nojaten hieman yli puolet vastaajista olisi niiden kannalla.

Kyselytulokset tukevat kalastuksen rajoittamista liian lämpimän veden aikaan ja vapautettavien kalojen ilma-altistuksen vähentämistä. Molemmat toimenpiteet puuttuivat täysin aineistonkeruuajan kalastussäännöistä, mikä heikensi säätelyn kestävyyttä. Huomioiden etenkin alueella tehtävät lohikalojen lisääntymisympäristöjen kunnostukset ja luontaisesti lisääntyvien kalakantojen palautustavoitteet, kalastusta yli +20 c vedessä on rajoitettava konkreettisesti. (Takkunen ym. 2018, 17.) Ruunaan monimuotoisuus on alueen valtti, sillä koskireitin välijärvissä elävät ahven-, hauki- ja kuhakannat kestävät lohikaloja paremmin pyyntiä myös lämpimän veden aikaan. Mikäli hellekausien kalastusta kohdennettaisiin järvialtaille, kalastusta ohjattaisiin kestävämmälle pohjalle laajentamalla hyödynnettävää kalaresurssia. 
Säätelyn kehittämisessä on huomioitava myös vapautettavien kalojen käsittely. Suositukset ilma-altistuksen vähentämisestä, kalojen limapintaa vahingoittamattomien haavien käyttämisestä sekä kalojen käsittelystä kostutetuin käsin eivät muodosta mittavaa menoerää, mutta yhdessä muun säätelyn kanssa ne vastaavat tarpeeseen saaliskalojen asiallisesta käsittelystä. Kyse on lopulta kalojen hyvinvointikysymyksistä, jotka on huomioitava kokonaisvaltaisesti kestävässä säätelyssä. (Arlinghaus ym. 2007, 67.)

Perhokalastajat suhtautuivat viehekalastajia suotuisammin kalastusrajoituksiin. Selittäviä tekijöitä rajoitusmyönteisyydelle löytyy ainakin kaksi: mahdollinen erikoistumisen taso ja rajoitusten vaikuttavuus suhteessa käytettäviin välineisiin. Perhokalastajissa oli lisäksi viehekalastajia enemmän pyydystä-ja-päästä-kalastajia sekä valikoivia kalastajia. Näissä ryhmissä suhtautuminen rajoituksiin on todennäköisesti myötämielisempää kuin kaloja pääasiassa ravinnokseen pyytävillä. Koukkujen määrä- ja väkäsrajoitukset koskevat todennäköisesti vahvemmin viehekalastajia, sillä perhokalastuksessa käytetään jo nykyisin varsin laajalti uusien sääntöjen mukaisia välineitä. Tällöin muutos perhokalastajille ei ole niin mittava, jolloin myös muutosvastarinnan voi olettaa olevan vähäisempi. Viehekalastajien keskuudessa ei oltu kategorisesti tiukemmin kaikkia uusia rajoituksia vastaan, vaan perhokalastajiin verrattuna suuret "en osaa sanoa" -osuudet korostuivat osassa säätelyväittämiä. Kyselyyn vastanneet viehekalastajat eivät siis aina osanneet arvioida säätelytoimien vaikuttavuutta samalla varmuudella kuin perhokalastajat.

Analyysin tulokset osoittavat mahdollisuuksia myös kalastajien kokemustiedon käytölle. Kalastajat ovat havainnoineet esimerkiksi harjuskannan heikkenemistä, mistä syystä harjukselle esitettiin osassa vastauksista täysrauhoitusta tai vähintään korkeampia alamittoja. Tulosten perusteella kalastajien kokemustietoa onkin mahdollista hyödyntää kalastusjärjestelyiden kehittämisessä, edellyttäen että saatua kokemustietoa pystytään peilaamaan ekologiseen tietoon. Ilman riittävää kontekstualisointia pelkät kokemukset eivät ole vielä kovin pitkälle johdettavia.

Tutkimusaineistojen keräämistä seuranneena vuonna 2020 Ruunaalle tuotiin maasto-opasteita, joilla kalastajia ohjataan vapautettavien saaliskalojen asialliseen käsittelyyn. Vastaavasti vuoden 2021 heinäkuussa Eräluvat.fi -sivuston Ruunaan koskilupien sivuille oli lisätty kalastajien ohjausta veden lämpötilaan liittyen. Ohjeistuksessa kalastajia kehotettiin välttämään kalastusta lupa-alueen yläosissa taimen- ja harjuskantojen 
turvaamiseksi. (Kirjallinen tiedoksianto 24.9.2021, Salla Niemetmaa, Eräpalvelut.) Toimenpiteet vastaavat konkreettisesti osaltaan joihinkin niihin kestävyysvajeen ongelmiin, joita olen tässä artikkelissa nostetanut esiin.

Kalastuksen säätelyssä Ruunaalla onkin edetty selvästi kohti aiempaa tietoperustaisempaa ja paremmin kestävyyttä tukevaa säätelyä, mutta konkreettisia puutteita on edelleen jäljellä. Keskeisimpiä seikkoja ovat vakioitu lämpötilaperustainen kalastuksen rajoittaminen sekä mahdollinen saaliskalojen välimittojen asettaminen. Vaikka uusiin rajoituksiin tai ohjaustoimiin ei päädyttäisikään, säätelyn sosiaalista hyväksyttävyyttä ajatellen nykyinenkin säätelymalli on syytä perustella avoimesti kalastajille, ettei sitä koettaisi pelkästään turhana, ylhäältä annettuna ja väärin kohdennettuna ohjeistuksena.

Vaikka tämän tapaustutkimuksen keskiössä ovat Ruunaan kosket, ei säätelyn kehittämisen, kalastajien tietotarpeisiin vastaamisen ja kalakannan hyvinvoinnin takaamisen asetelma ole yksin itäsuomalaisen syrjäseudun ilmiö. Mikäli suomalaista maaseutua halutaan tukea esimerkiksi kalastusmatkailua kehittämällä, kalastajien tuntemus ja säätelyn tietoperustaisuus sekä näistä yhdessä syntyvä toiminnan sosiaalis-ekologinen kestävyys ovat kalastuskohteiden kehittämisen ytimessä. Laajemmin katsoen, virkistyskalastajien ja koskikohteiden lukumäärä sekä kalastuksen kestävyyden tavoittelun tarve huomioiden myös kalastajien kokemuksia on kuultava. Ilman kattavaa tietoa säätelyn vaikuttavuudesta tai kalastajien suhtautumisesta eri säätelytoimiin kokonaisuutta on haastavaa saada kestävälle pohjalle.

Maaseutualueilla sijaitsevat virkistyskalastuskohteet muodostavat valtakunnallisesti katsoen hyvin mittavan, ekologisen ja taloudellisen resurssipohjan, jonka hyödyntämisestä kalastajat kilpailevat. Kalojen kaltaiseen resurssiin liittyy kuitenkin erottamattomana piirteenä rajallisuus: kalakannat eivät ole pohjattomia eivätkä ne kestä liiallista pyyntiä. (McWhinnie 2009.) Ruunaan kaltaisissa erityislupakohteissa kalakantojen säilyminen on osaltaan turvattu pyyntikiintiöiden avulla, ja toiminnan kokonaisvaltaista kestävyyttä voidaan parantaa edelleen riittävällä säätelyllä niin pyyntivälineiden kuin -olosuhteiden osalta, mikäli näin vain halutaan.

Samaan aikaan etenkin erityislupakohteiden ulkopuolella tapahtuva kiintiöimätön pyynti luo mahdollisuuden yhteismaan tragedialle, joka on 
todellinen riski kalaveden laajuudesta tai pyydettävästä kalalajista riippumatta (Berkes 1985). Suomen maaseutualueet ja niiden kalakannat eivät ole tälle riskille immuuneja, mikä on syytä huomioida etenkin vesistökohtaisessa säätelyssä, mikäli tavoitteena on kalavarojen ekologisesti kestävä käyttö uuden kalastuslain tavoitteiden mukaisesti. (Haapasalo 2020.)

Tietoperustaisen, ekologista kestävyyttä tukevan ja kalojen hyvinvoinnin huomioivan säätelyn varaan perustuvalle virkistyskalastukselle on helppo ennustaa suotuisaa jatkoa muuttuvassa yhteiskunnassa.

Kiitokset: Tätä tutkimusta on rahoittanut Suomen Kulttuurirahaston Pohjois-Karjalan rahasto.

\section{Kirjallisuus}

Arlinghaus, R., Cooke S.J. \& W Potts. 2013. Towards resilient recreational fisheries on a global scale through improved understanding of fish and fish behaviour. Fisheries management and Ecology, 20, 91-98.

Arlinghaus, Robert 2005. A conceptual framework to identify and understand conflicts in recreational fisheries systems, with implications for sustainable management. Aquatic Resources, Culture and Development 1(2), 145-174.

Arlinghaus, Robert, Cooke Steven J., Schwab Alexander \& Ian G Cowx. 2007. Fish welfare: a challenge to the feelings-based approach, with implications for recreational fishing. Fish and Fisheries 8, 57-71.

Ayllón, Daniel, Nicola Graciela G., Elvira Benigno \& Ana Almodóvar 2019. Optimal harvest regulations under conflicting tradeoffs between conservation and recreational fishery objectives. Fishers Research 216, 47-58

Bartholomew, Aaron \& James A. Bohnsack 2005. A Review of Catch-and-Release Angling Mortality with Implications for No-take Reserves. Reviews in Fish Biology and Fisheries.

Berkes, Fikret 1985. Fishermen and the tragedy of the commons. Environmental conservation, vol 12. no. 3. 199-206. Cambridge University Press.

Boonstra, Wiebren J., Birnbaum Simon \& Emma Björkvik 2017. The quality of compliance: investigating fishers' responses towards regulation and authorities. Fish and Fisheries 18.

Boyd, James W., Guy, Christopher S., Horton, Travis B. \& Stephen A Leathe. 2010. Effects of Catch-and-Release Angling on Salmonids at Elevated Water Temperatures. North American Journal of Fisheries Management 30:898-907.

Brownscombe, Jacob W., Danylchuk Andy J., Chapmana, Jacqueline M., Gutowska, F.G. \& Steven J Cooke . 2017. Best practices for catch-and-release recreational fisheries - angling tools and tactics. Fisheries Research 186, 693-705 
Charles, T. Anthony 2001. Sustainable fishery systems. Fish and aquatic resources series 5. Blackwell Science.

Cook, V. Katrina, Lennox, Robert James, Hinch, Scott G. \& Steven Cooke 2015. Fish out of water: How Much Air is Too Much? Fisheries 40, 9.

Cooke, Steven J., Twardek William M., Reid Andrea J., Lennox Robert J., Danylchuk Sascha C., Brownscombe Jacob W., Bower Shannon D., Arlinghaus Robert, Hyder Kieran \& Andy J Danylchuk. 2019. Searching for responsible and sustainable recreational fisheries in the Anthropocene. Journal of Fish Biology, 94: 845-856.

De Houwer, Jan, Gawronski Bertram \& Dermot Barnes-Holmes 2013. A Functional-cognitive framework for attitude research. European review of social pshychology, vol. 24, no. 1.

Eisto, llkka 2009. Kylläpä kestää - Paikallisesti kestävän kehityksen ja ympäristölähtöisen kehittämistoiminnan suhde harvaanasutulla maaseudulla. Joensuun yliopistopaino, Joensuu.

Gambino, Monica, Malvarosa Loretta \& Vincenzo Placenti 2003. Fishery regulation, perceptions and compliance: The fishermen responses. Economic Research Institute on Fisheries and Aquaculture, Salerno.

Gwinn, Daniel C., Allen Michael S., Johnston Fiona D., Brown Paul, Todd Charles R. \& Robert Arlinghaus 2015. Rethinking length-based fisheries regulations: the value of protecting old and large fish with harvest slots. Fish and Fisheries, 16, 259-281.

Haapasalo, Timo 2020. Antroposentrismistä ekosysteemiseen ajatteluun?

Diskurssianalyyttinen tutkimus kalastuslainsäädännön tavoitteiden muutoksesta.

Alue ja Ympäristö, vol.49, no1.

Hall-Arber, Madeleine, Pomeroy Caroline \& Flaxen Conway 2009. Figuring out the human dimensions of fisheries: Illuminating models. Marine and Coastal Fisheries:

Dynamics, Management and Ecosystem Science 1:300-314. American Fisheries Society.

Heikkilä, Tarja, 2014. Tilastollinen tutkimus. Edita Publishing Oy, Helsinki.

Hind, Edward J. 2015. A review of the past, the present, and the future of fishers' knowledge research: a challenge to established fisheries science. ICES Journal of Marine Science, 72(2).

Hobson, Bryan 2000. Recreation specialization revisited. Journal of Leisure Research, vol 32. no1.

Hunt, L.M., Sutton S.G. \& Robert Arlinghaus 2013. Illustrating the critical role of human dimensions research for understanding and managing recreational fisheries within a social-ecological system framework. Fisheries management and Ecology, 20, 111-124.

Joubert, B.A., Sullivan M. G., Kissinger B.C. \& A.T. Meinke 2020. Can smartphones kill Trout? Mortality of memorable-sized Bull Trout (Salvelinus confluentus) after photo-releases. Fisheries Research 223.

Kalastusasetus 1360/2015, Finlex.

Kirjallinen tiedoksianto 24.9.2021. Suunnittelija Salla Niemetmaa, Eräpalvelut, Metsähallitus.

Knoche, Scott \& Frank Lupi 2016. Demand for fishery regulations: Effects of angler heterogeneity and catch improvements on preferences for gear and harvest restrictions. Fisheries Research 181, 163-171.

Koljonen, Saija 2011. Ecological impacts of in-stream restoration in salmonid rivers, The role of enhanced structural complexity. Jyväskylän yliopisto. 
Koskiensuojelulaki 379/2015, Finlex.

McWhinnie, Stephanie F. 2009. The tragedy of the commons in international fisheries: An empirical examination. Journal of Environmental Economics and Management 57, 321-333.

Meka, Julie M. \& Stephen D. McCormick 2005. Physiological response of wild rainbow trout to angling: impact of angling duration, fish size, body condition, and temperature. Fisheries Research 72, 311-322.

Muje, Kari, Veistämö Tommi, Rautiainen Tommi \& Jukka Syrjänen 2019. Kestävyyttä tukevat hallintokäytännöt. Alue ja ympäristö 48:1, 46-67.

Murphy, Jr. Robert, Scyphers Steven, Gray Steven \& Jonathan H. Grabowski 2019. Angler attitudes explain disparate behavioral reactions to fishery regulations. Fisheries, 1.

Nguyen, Vivian M., Rudd Murray A., Hinch Scott G. \& Steven J. Cooke 2013. Recreational anglers' attitudes, beliefs, and behaviors related to catch-and-release practices of Pacific salmon in British Columbia. Journal of Environmental Management 128, 852-865.

Oh, Chi-Ok \& Robert B. Ditton 2008. Using Recreation Specialization to Understand Conservation Support, Journal of Leisure Research, 40:4, 556-573.

Oksanen, Minna 2004. Rajauitot - osa Lieksan savotta- ja uittohistoriaa. Teoksessa: Hukan hännän mitalla - rajaseudun historiaa Lieksasta. Saarelainen Asko (toim.) Gummerrus Kirjapaino oy, Jyväskylä

Olin, M., Tiainen, J., Rask, M., Vinni, M., Nyberg, K. \& Lehtonen, H. 2017. Effects of non-selective and size-selective fishing on perch populations in a small lake. Boreal Environment Research, 22: 137-155.

Oystein, Aas \& Len Hunt 2000. Angler responses to potential harvest regulations in a Norwegian sport fishery: A conjoint-based choice modelling approach. North American journal of fisheries management, 20:4, 940-950.

Page, Kevin S. \& Paul J Radomski. 2006. Compliance with sport fishery regulations in Minnesota as related to regulation awareness. Fisheries vol. 31, no 4.

Paulus, Elina, 2019. Ruunaan retkeilyalueen kävijätutkimus. Metsähallituksen Iuonnonsuojelujulkaisuja, sarja B 243. Metsähallitus, Vantaa.

Pauly, Daniel, Christensen Villy, Guenette Sylvie, Pitcher Tony J., Sumaila Rashid U., Walters Carl J., Watson R. \& Dirk Zeller 2002. Towards sustainability in world fisheries. Nature 418: 689-695.

Pellikka, Jani \& Päivi Eskelinen 2019. Vapaa-ajankalastajien profiilit. Luonnonvara- ja biotalouden tutkimus 41/2019. Luonnonvarakeskus.

Pohja-Mykrä Mari, Matilainen Anne, Kujala Susanna, Hakala Outi, Harvio Viktor, Törmä Hannu \&Sami Kurki, 2018. Erätalouteen liittyvän yritystoiminnan nykytila ja kehittämisedellytykset. Valtioneuvoston selvitys ja tutkimustoiminnan julkaisusarja.

Ruunaan hoito- ja käyttösuunnitelma, 2002. Metsähallitus, Vantaa.

Ruunaan koski- ja virta-alueet määriteltiin. Pilkkikielto selkiytyi. 29.12.2020, Metsähallitus, Eräluvat.fi <https://www.eraluvat.fi/ajankohtaista/ajankohtaiset-aiheet/uutiset/ ruunaan-koski-ja-virta-alueet-maariteltiin.-pilkkikielto-selkiytyi.>

Salz, Ronald J. \& David K. Loomis 2005. Recreation specialization and anglers' attitudes towards restricted fishing areas. Human dimensions of wildlife, 10: 187-199. 
Schisler, George J. \& Eric P. Bergersen 1996. Postrelease hooking mortality of rainbow trout caught on scented artificial baits. North American Journal of Fisheries management, 16:570-578.

Stead, Selina, Daw Tim \& Tim Gray 2006. Uses of Fishers' Knowledge in Fisheries Management. Anthropology in Action, 13, 3: 77-86. DOI:10.3167/aia.2006.130308.

Steelman, Toddi A. \& Richard Wallace 2001. Property rights and property wrongs: Why context matters in fisheries management. Policy sciences, vol. 34, no $3 / 4 . p p$. 357-379.

Stephenson, Robert L., Paul Stacey, Pastoors Martin A., Kraan Marloes, Holm Petter, Wiber Melanie, Mackinson Steven, Dankel Dorothy J., Brooks Kate \& Ashleen Benson 2016. Integrating fishers' knowledge research in science and management. ICES Journal of Marine Science, 73(6), 1459-1465. doi:10.1093/icesjms/fsw025.

Takkunen, Timo, Piironen Jorma, Kaijomaa Veli-Matti, Hyytinen Lasse, Makkonen Jarmo, Vanninen Vesa, Malin Mikko, Hentinen Teemu, Jaatinen Rauno, Kiiskinen, Päivi, Tarkiainen Janne \& Joonas Rajala (toim.) 2018. Vuoksen vesistöalueen järvitaimenkantojen toimenpideohjelma. Raportteja 60, Pohjois-Savon ELY-keskus.

Thomas, Alyssa S., Milfont Taciano L. \& Michael C. Gavin 2014. What determines fishers' knowledge of and attitudes towards regulations? A case study from the Marlborough Sounds, New Zealand. Marine policy 51, 547-554.

Tiainen, J., Olin, M., Lehtonen, H., Nyberg, K. \& Ruuhijärvi, J. 2017. The capability of harvestable slot-length limit regulation in conserving large and old northern pike (Esox lucius). Boreal Environment Research, 22: 169-186.

Toivonen, Anna-Liisa, Mikkoja Jukka \& Pekka Salmi 2003. Vapaa-ajankalastuksen monet merkitykset. Kalatutkimuksia 187. Riista- ja kalatalouden tutkimuslaitos, Helsinki.

Tuomi, Jouni \& Anneli Sarajärvi 2018. Laadullinen tutkimus ja sisällönanalyysi. Kustannusosakeyhtiö Tammi.

Vapaa-ajankalastus, Luonnonvarakeskus 2018. <https://www.luke.fi/tietoa-luonnonvaroista/ kalat-ja-kalatalous/vapaa-ajankalastus/>

Vesala, Kari Mikko \& Teemu Rantanen 2007. Argumentaatio ja tulkinta: laadullisenasennetutkimuksen lähestymistapa. Gaudeamus. 